\title{
Post-cracking behavior of blocks, prisms, and small concrete walls reinforced with plant fiber
}

\section{Comportamento pós-fissuração de blocos, prismas e pequenas paredes de concreto reforçado com fibra vegetal}
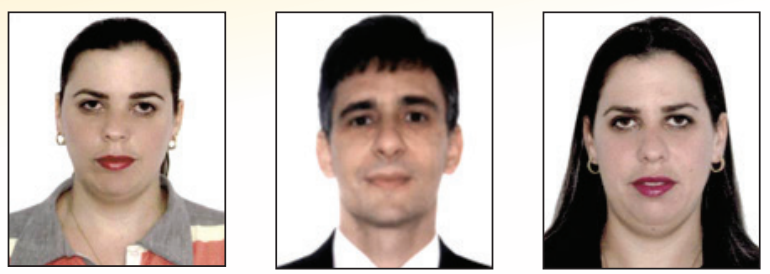

I. I. SOTO a indara@sc.usp.br

M. A. RAMALHO a ramalho@usp.br

O. S. IZQUIERDO a orieta@sc.usp.br

\section{Abstract}

Structural masonry using concrete blocks promotes the rationalization of construction projects, lowering the final cost of a building through the elimination of forms and the reduction of the consumption of reinforcement bars. Moreover, production of a block containing a combination of concrete and vegetable fiber sisal results in a unit with properties such as mechanical strength, stiffness, flexibility, ability to absorb energy, and post-cracking behavior that are comparable to those of a block produced with plain concrete. Herein are reported the results of a study on the post-cracking behavior of blocks, prisms, and small walls reinforced with sisal fibers (lengths of $20 \mathrm{~mm}$ and $40 \mathrm{~mm}$ ) added at volume fractions of $0.5 \%$ and $1 \%$. Tests were performed to characterize the fibers and blocks and to determine the compressive strength of the units, prisms, and small walls. The deformation modulus of the elements was calculated and the stress-strain curves were plotted to gain a better understanding of the values obtained. The compression test results for the small walls reinforced with fibers were similar to those of the reference walls and better than the blocks and prisms with added fibers, which had resistances lower than those of the corresponding conventional materials. All elements prepared with the addition of sisal exhibited an increase in the deformation capacity (conferred by the fibers), which was observed in the stress-strain curves. The failure mode of the reference elements was characterized by an abrupt fracture, whereas the reinforced elements underwent ductile breakage. This result was because of the presence of the fibers, which remained attached to the faces of the cracks via adhesion to the cement matrix, thus preventing loss of continuity in the material. Therefore, the cement/plant fiber composites are advantageous in terms of their ductility and ability to resist further damage after cracking.

Keywords: vegetable fiber, post-cracking behavior, structural masonry.

\section{Resumo}

A alvenaria estrutural com blocos de concreto promove a racionalização da construção, com redução do custo final da edificação, por meio da eliminação de fôrmas e da redução do consumo de armaduras. Além disso, produzir um bloco com a combinação de concreto e fibra vegetal de sisal resulta em uma unidade que apresenta características mais apropriadas de resistência mecânica, rigidez, ductilidade, capacidade de absorção de energia e comportamento pós-fissuração, em comparação com o bloco produzido com o concreto simples. O presente trabalho avalia o comportamento pós-fissuração de blocos, prismas e pequenas paredes de concreto reforçado com fibra de sisal de comprimento 20 e $40 \mathrm{~mm}$, e fração volumétrica de 0,5 e $1 \%$. Foram realizados os testes de caracterização da fibra e do bloco, e os ensaios de resistência à compressão axial das unidades, dos prismas e das pequenas paredes. 0 módulo de deformação dos elementos foi calculado e foram traçados os diagramas tensão-deformação para uma melhor interpretação dos valores obtidos Os resultados do ensaio à compressão das pequenas paredes reforçadas com fibras foram similares aos valores das paredes de referência, apresentando melhor desempenho que os blocos e prismas com adição de fibras, cujas resistências foram inferiores aos convencionais. Todos os elementos com adição de sisal mostraram um ganho da capacidade de deformação conferida pelas fibras, observado nos diagramas tensão-deformação. O modo de ruptura dos elementos de referência foi caracterizado por uma fratura brusca e os reforçados tiveram um rompimento dúctil. Isso foi produzido pelas fibras, que mantiveram as faces das fissuras unidas em razão da aderência com a matriz cimentícia, não permitindo a perda da continuidade do material e tornando os compósitos vantajosos em termos de ductilidade e capacidade de resistência residual após a fissuração.

Palavras-chave: fibra vegetal, comportamento pós-fissuração, alvenaria estrutural. 


\section{Introduction}

The growing study of new materials with good performance and low cost has led to the use of vegetable fibers as replacements for synthetic fibers that are typically employed as reinforcement in composites. Tropical countries such as Brazil have an abundance and diversity of vegetable crops, and thus a large supply of fibers, enabling their use in construction elements. The overall goal is to improve the physical and mechanical properties of construction materials to be able to build higher performing structures.

Several studies have been developed with respect to the fibrous residues from agroindustry, including sisal fibers, banana peels, and the pulp from eucalyptus trees, among others. Noteworthy is the work of Holmer Savastano Jr. [1], who showed that agricultural waste can be used as a raw material for the reinforcement of alternative cementitious matrices and determined that optimal physical performance and adequate structural integrity in manufactured concrete elements could be obtained. Priscilla Pereira [2] evaluated the addition of piaçava fibers to concrete for the manufacture of blocks and prepared a unit with higher tensile strength and optimal conditions for use. Ventura [3] performed bending tests on three different locations in concrete specimens reinforced with sisal fiber, demonstrating that the composite had a greater capacity for deformation than a conventional composite. The aim of Marcelo de Souza Picanço [4] was to study the effect of the addition of curauá fiber, sisal, coir, and jute to cementitious composites with the view of replacing asbestos. The results indicated that the fibers conferred higher ductility and resilience after matrix cracking.

The interest in the use of vegetable fibers as reinforcement materials in concrete is linked to their low cost, high availability, and low energy consumption for production. In addition to the economic benefits, vegetable fibers improve the mechanical performance of these materials, such as increasing the tensile strength, controlling the opening and propagation of cracks, and reducing the stiffness of composites, thus making them more ductile and able to undergo greater deformations without loss of integrity (Savastano) [1]

\subsection{Sisal fiber}

Sisal is a plant resistant to dry weather and intense sun exposure and is cultivated in tropical and subtropical regions. It is a common plant in northeastern Brazil, with nearly a million workers directly dependent on this plant for their livelihoods.

Currently, Brazil is the largest producer of sisal in the world, and the state of Bahia is responsible for $80 \%$ of the nation's fiber production. The sisal is formed into fiber sheets that, after beneficiation, are intended mainly for use in the rope and craft industries for the manufacture of twine, bags, some types of fabrics, reinforcing wire cable, pipes, nets, and carpets. Although the use of the fiber is most popular in the industry manufacturing rope, its value can be increased if used as a reinforcement for composites. Among other advantages, one can point to its abundance in Brazil, ease of cultivation, biodegradability, the fact that it is a renewable resource, and its good properties such as thermal and acoustic insulation. These factors coupled with its high toughness, abrasion resistance, and low cost make sisal one of the most studied natural fibers.
Because of a high incidence of permeable pores, including gaps and lumens, vegetable fibers, including sisal fibers, have a smaller apparent density than their actual density and also a high water absorption (greater than 90\%), which affects their adherence to cementitious matrices (Savastano [5]).

The loss of ductility in moist and alkaline environment, high water absorption and the heterogeneity of their physical and mechanical properties are the most important factors that adversely affect the performance of vegetable fibers, when applied to reinforcement matrices based on Portland cement.

Sisal fibers, despite having characteristics that may negatively affect the reinforcement of Portland cement pastes, also have other favorable attributes that contribute to the good performance of such composites. These positive factors can be better leveraged with the development of improved production techniques and appropriate conservation of these fibers.

\subsection{Composite materials}

A composite is typically formed of two phases: the matrix and the reinforcing element. Matrices consist of agglomerates and mineral aggregates that result in concrete, mortar, or pastes according to the specific application. In simplified form, the reinforcing components impart additional strength by transferring and homogeneously distributing forces throughout the matrix. In addition, the fibers act as obstacles that inhibit the propagation of cracks, leading to progressive ruptures by partially absorbing the energy associated with them, thus ensuring that the capacity of an element is retained (Caetano et al. [6]).

Furthermore, parameters such as quantity, relative volume, length, shape, and orientation of the fibers influence the performance of the composite materials.

With a higher quantity of fibers, the number of microcracks intercepted by the fibers increases, improving the strength and toughness. The performance of the set improves because the propagation of cracks is slowed and the maximum tension is increased because of the increase in the mechanical strength. The mechanical strength is also enhanced because the load imposed on the matrix is partially transferred to the fibers, which then absorb some of the internal tension.

On the other hand, increasing the amount of fiber is intrinsically linked to a reduction in the workability of the mixture due to the absorption of water and the wettability, which can cause consistency problems (Caetano et al. [6]).

\subsection{Mechanism of rupture in masonry elements}

In masonry walls or prisms, forces of all types may occur, such as compression, tensile, bending, and shear forces. The function of the mortar is to uniformly absorb and transmit these forces.

Medeiros [7] cites Hilsdorf theory to explain the rupture of typical vertically loaded masonry walls built with blocks seated using lateral completion of the horizontal joints, which occurs through the propagation of vertical cracks in the upper wall thickness. According to this theory, also known as the Tensile Transverse Fracture Mechanism, rupture is caused by the difference in stiffness between the mortar and block. Because of this difference, when the wall is subjected to compression, the deformation of the laterally 


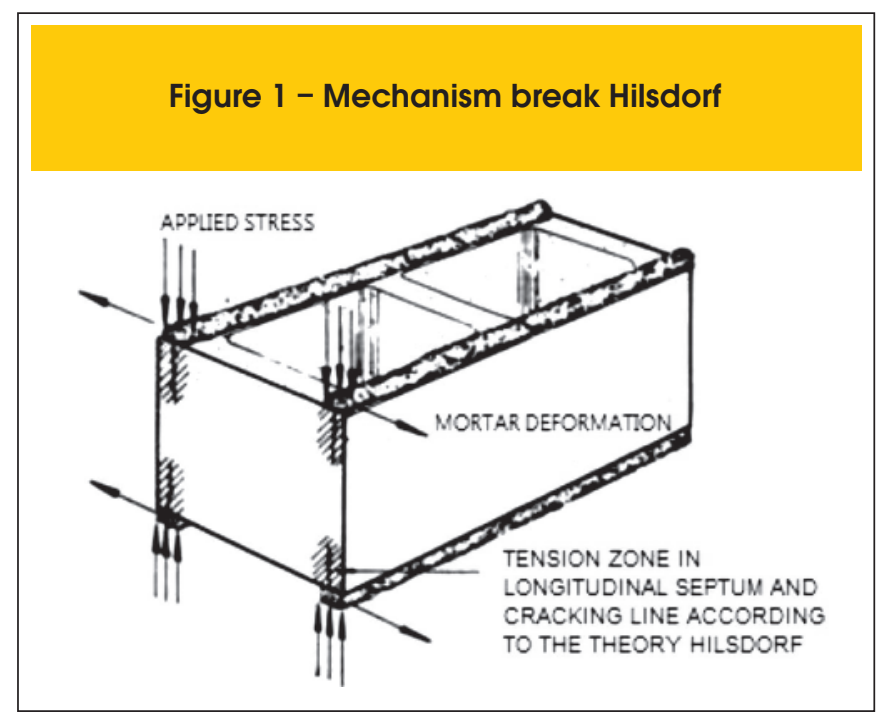

confined mortar causes transverse tension in the blocks (Figure 1). According to Solórzano [8], authors such as Lenczner (1972), Sutherland (1981), and Sinha \& Hendry (1987) show full agreement that bi- and triaxial stresses produced in masonry are subjected to compressive stress. These forces occur because of the different deformation moduli of the materials used for the construction of the prisms and walls. According to the abovementioned theory, the mortar is less rigid than the blocks; i.e., it has a greater deformation under load and tends to be expelled. Accordingly, the deformation induced in a mortar produces lateral tensions tangential to the plane of the joint that are restricted by the masonry units. These are thus subjected to traction lateral stresses that cause rupture through the development of cracks parallel to the axis of loading.

Figure 2 shows the state of the triaxial compression stress in the mortar and the lateral axial traction in the blocks.

\section{Figure 2 - Strains on the block and the mortar joint when subjected to axial compression}

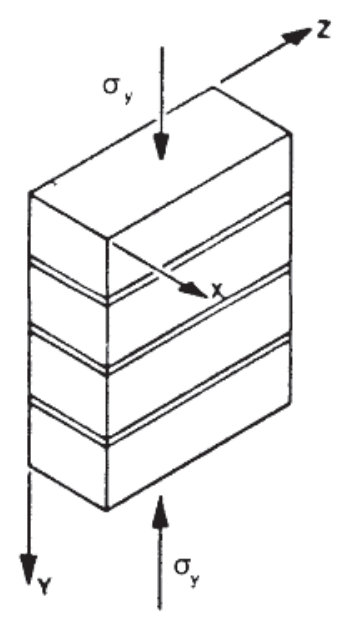

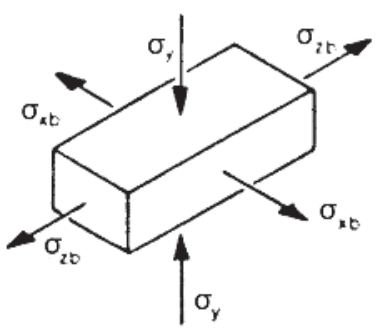

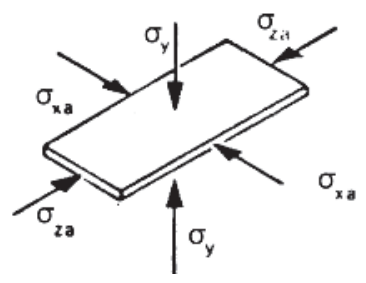

Table 1 - Type series of blocks manufactured

\begin{tabular}{|ccc|}
$\begin{array}{c}\text { Classification } \\
\text { block } \\
\text { structural }\end{array}$ & $\begin{array}{c}\text { Fiber } \\
\text { content } \\
(\%)\end{array}$ & $\begin{array}{c}\text { Fiber } \\
\text { length } \\
(\mathrm{mm})\end{array}$ \\
\hline BE & - & - \\
BE20-0,5\% & 0,5 & 20 \\
BE40-0,5\% & 0,5 & 40 \\
BE20-1\% & 1 & 20 \\
BE40-1\% & 1 & 40 \\
\hline
\end{tabular}

For concrete masonry, the rupture usually occurs because of traction in a block under relatively low compressive stress, and the lateral traction is the dominant strain in the biaxial state. Thus, the function of existing fibers in concrete blocks is of reinforcement. The fibers allow the transfer of tensile forces, decrease crack propagation, control crack opening, and can help delay the rupture of masonry units.

Thus, the main objectives of this research were to evaluate the post-cracking behavior of blocks, prisms, and small concrete walls reinforced with sisal fiber through axial compression tests and determination of the deformation modulus.

\section{Materials and experimental program}

The composites were produced using sisal fibers provided by Sisal Weaving (Tecsal, State of Bahia, Brazil). These Type 3 sisal fibers are used to make general yarns and Bale Twine, a type of agricultural yarn, for export. Sisal fibers with lengths of $20 \mathrm{~mm}$ and $40 \mathrm{~mm}$ were incorporated at volumetric fractions of $0.5 \%$ and $1 \%$ in concrete. The density, water absorption, and moisture content of the fibers were determined.

Blocks of concrete with and without fibers were manufactured with a characteristic strength of $4 \mathrm{MPa}$ at Tatu Precast (Limeira, São Paulo, Brazil). Five series were produced in total, with the first series as a reference. The remaining series were differentiated by the added fiber content compared to the volume of concrete and length of the fibers. Table 1 presents the nomenclature for the building blocks in each series.

Axial compression tests were performed on the blocks, prisms, and small walls constructed using the concrete with and without added fibers according to NBR 12118: 2007 [9] for the blocks, NBR 8215: 1983 [10] for the prisms, and NBR 8949: 1985 [11] for the small walls. The equipment used for the tests belonged to the Structures Laboratory of the School of Engineering of São Carlos (EESC) at the University of São Paulo (USP). A total of 90 blocks (18 per series), 60 prisms, (12 per series), and 15 walls (three per series) were tested. The modulus of deformation was calculated for the prisms and small walls in accordance with the requirements of the $\mathrm{ACI}$ 530-92 standard [12]. According to this standard, the modulus is given by the slope of the secant line on the stress-strain diagram between $5 \%$ and $33 \%$ of the rupture strain.

A linear variable differential transformer (LVDT) was used for the measurements. Two displacement transducers were 


\section{Figure 3 - Front and plan view of the location displacement transducers prisms}

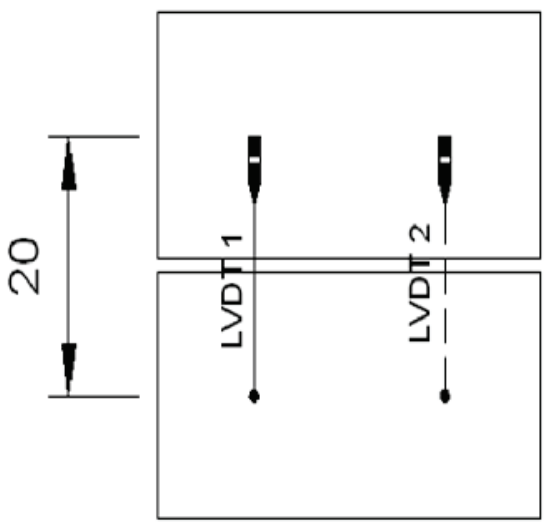

used for the prisms and four for the small walls to create a maximum measurement field for a displacement of $20 \mathrm{~mm}$ and a resolution of $0.001 \mathrm{~mm}$. The speed of the enforcement displacement was $0.005 \mathrm{~mm} / \mathrm{s}$, and the measurements were recorded every $1.5 \mathrm{~s}$ using the SYSTEM 5000 data acquisition and storage system.

Figures 3 and 4 contain the illustrations of the instrument and locations of the displacement transducers on the prisms and small walls, respectively.

Testing of the compressive strength of the blocks was achieved using an ELE brand Autotest 2000 press with a capacity of 2000 $\mathrm{kN}$ that was equipped with two supporting plates (Figure 5). The

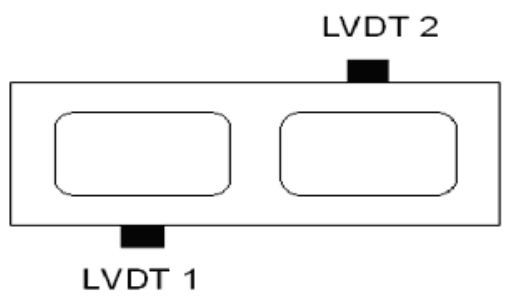

blocks were air dried and tested using power control at a constant speed of $2.03 \mathrm{kN} / \mathrm{sec}$.

The prisms and small walls were tested in a servo-controlled INSTRON 8506 instrument with System 5000 for data acquisition (Figure 6). These elements were tested with displacement control and a constant speed of $0.005 \mathrm{~mm} / \mathrm{s}$. A $35-\mathrm{mm}$-thick steel plate and a steel profile were placed on the tops of the prisms and small walls, respectively, to generate the uniform distribution of the load. Only one type of mortar was used for the fabrication of the prisms and small walls. The mortar was a mixture of cement, lime, and sand, and is the most suitable for use in masonry structures. The British Standard BS 5628: Part 1: 1992 [13] prescribes traces for medium

Figure 4 - Front and plan view of the location displacement transducers small walls
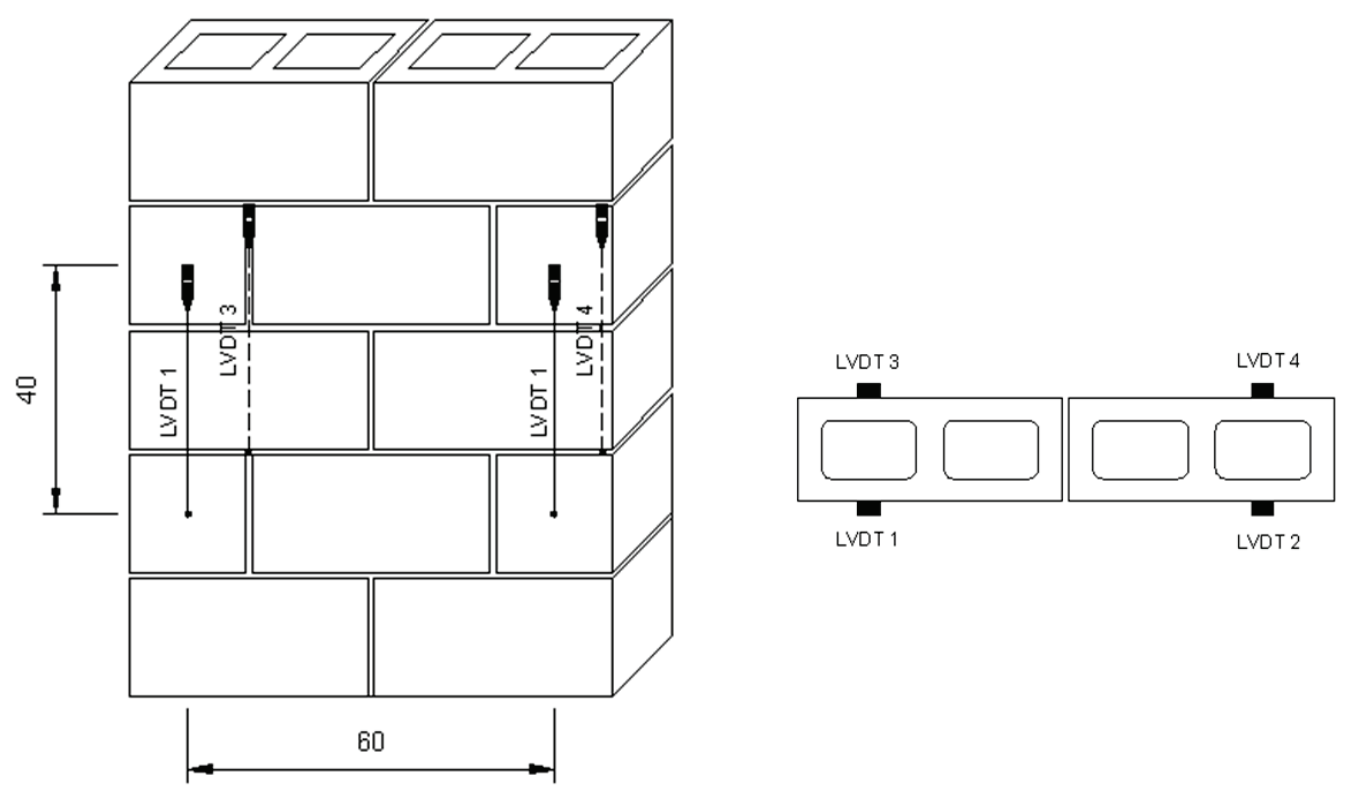
and low resistance. A medium resistance mortar was chosen with a trace volume of 1:0.5:4.5 for cement, lime, and sand, respectively.

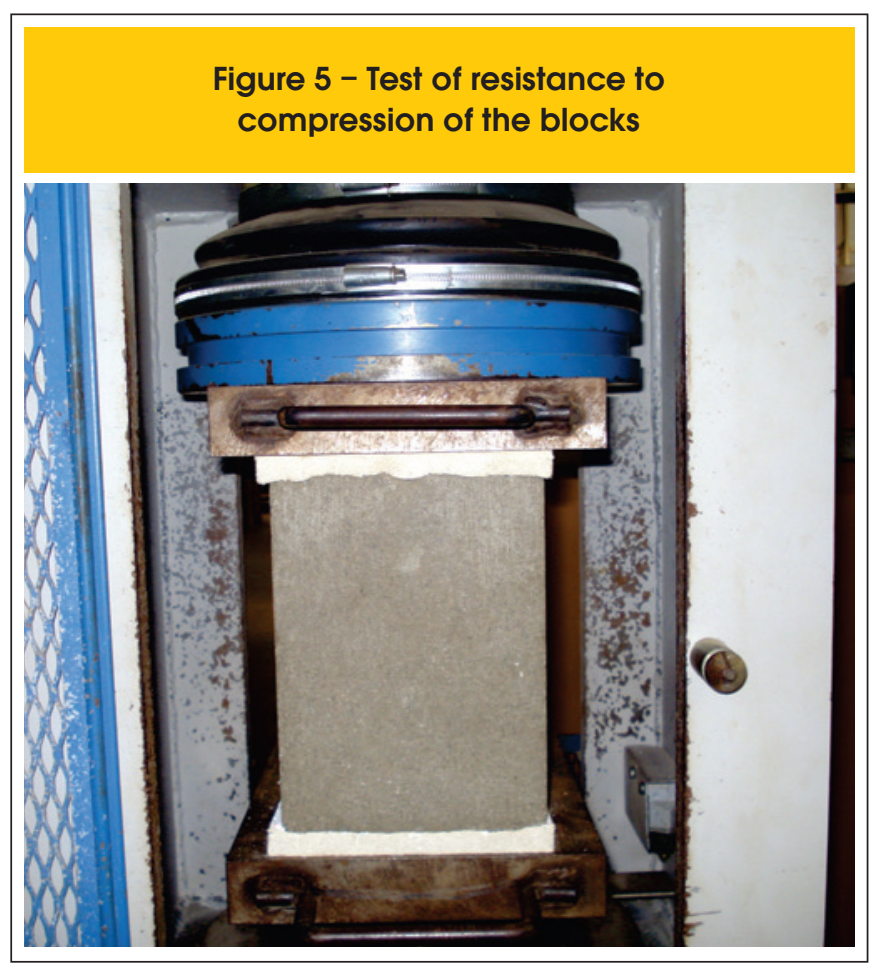

For a better understanding of the results and to obtain satisfactory conclusions, a statistical analysis of the influence of fiber addition on the compressive strength of the blocks, prisms, and small walls was also conducted using the program OriginPro 7.5.

\subsection{Block manufacturing process}

The materials used to manufacture the blocks were CPV ARI PLUS cement, gravel, stone powder, and sand. In compliance with the company's environmental policy, a recycled aggregate was used as a replacement for $30 \%$ of the natural aggregates. The recycled aggregate originated from recyclable elements rejected by quality control, the remains of fresh concrete, and units damaged during transport and storage (Figure 7).

The blocks were produced on an industrial scale in the TATU factory and were precast using the same trace for each type of unit in which all inputs-with the exception of the cement and fibers-were measured in volume. The sisal fibers and cement were weighed separately and placed directly into the mixer. Adjustment of the water content of the trace for each series of blocks was performed on the basis of a visual evaluation by the molding operator. The blocks were produced in a Piorotti BLOCOPAC 1300 vibropress for different production times. The use of this type of equipment allows for the production of units with high strength, good workmanship, low cement consumption, and good compaction of the concrete.

The order of presentation of the materials followed the appropriate sequence for the equipment used. Initially, the amount of all

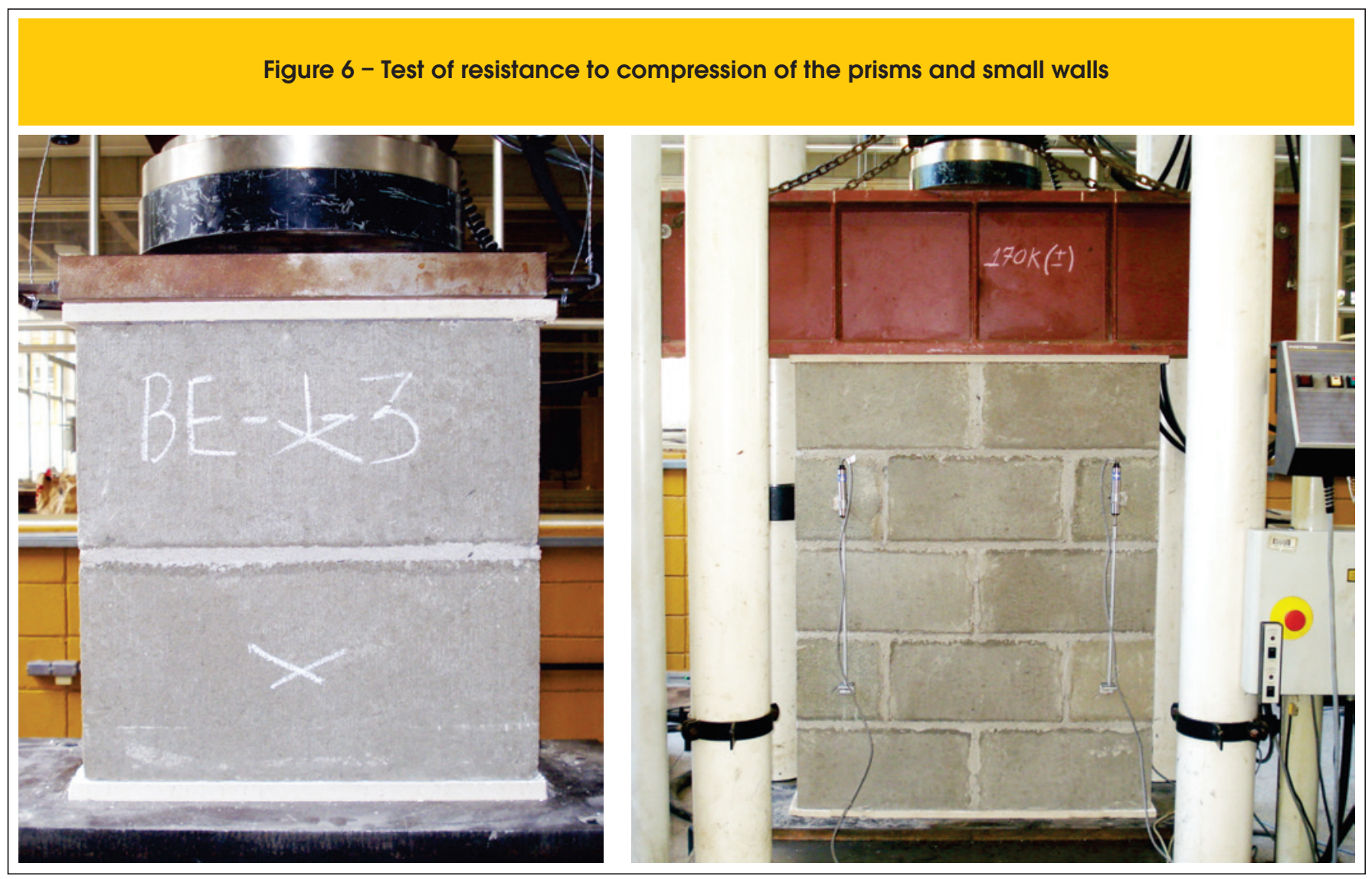




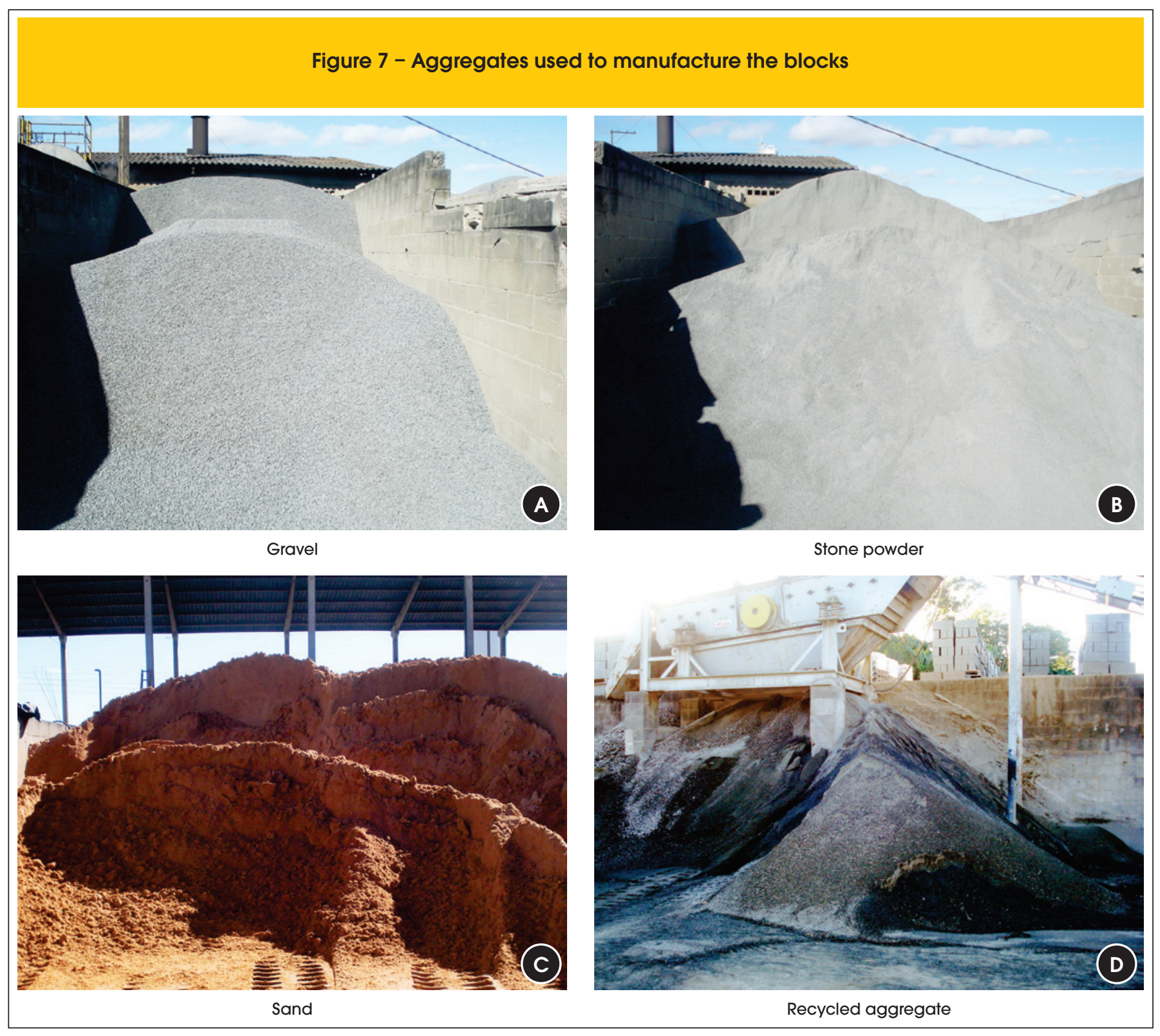

aggregates was determined. After the introduction of the cement and fibers (for the blocks containing fibers), the material was mixed for about $1 \mathrm{~min}$. Water and additives were then added, and the final blend was mixed for approximately $3 \mathrm{~min}$.

The molding of the blocks was achieved by adjusting the feeding times, vibration, agitation, and demolding of the vibro-press. In defining these times, the experience of the molding operator was essential. After completion of the pressing, the freshly molded blocks were transferred to cure chambers. Thermal curing was achieved overnight and consisted of a cycle lasting $4-5 \mathrm{~h}$ at a constant temperature of $60^{\circ} \mathrm{C}$.

\section{Results and discussion}

The results are presented with their respective analyses. The values are displayed in tables that include the mean, standard devia- tion (Sd), and coefficient of variation (CV) for each of the samples. Statistical tests included an analysis of variance (ANOVA) test with one factor and an ANOVA with two factors. The first test indicated that if there were any statistically significant differences between the compressive strength of the blocks, prisms, and small walls as a result of the small addition of fibers. On the other hand, the second test indicated if the length and volume content of the fibers influenced the compressive strength of the blocks, prisms, and small walls.

\subsection{Physical properties of the fibers and blocks}

Table 2 lists the physical properties of the fibers. The low apparent density and high water absorption are common characteristics of vegetable fibers because of the large number of permeable pores, including gaps and lumens. 
Table 2 - Physical characterization of sisal fiber

\begin{tabular}{|c|c|c|c|}
\hline Values & $\begin{array}{c}\text { Real } \\
\text { density } \\
\left(\mathrm{kg} / \mathrm{m}^{3}\right)\end{array}$ & $\begin{array}{c}\text { Apparent } \\
\text { density } \\
\left(\mathrm{kg} / \mathrm{m}^{3}\right)\end{array}$ & $\begin{array}{c}\text { Water } \\
\text { absorption } \\
24 \mathrm{~h}(\%)\end{array}$ \\
\hline Average & 970,62 & 740,22 & 139 \\
\hline Sd & 31,42 & 30,52 & 0,59 \\
\hline CV (\%) & 3,24 & 4,12 & 5,68 \\
\hline
\end{tabular}

Savastano [1] obtained apparent density values of sisal fiber between 400 and $500 \mathrm{~kg} / \mathrm{m} 3$, which are lower than those obtained for the fibers used in this study. The values for the maximum water absorption over $24 \mathrm{~h}$ were also lower than those reported by Toledo Filho [14] and Savastano [1] (193\% and 151\%, respectively). The results of the density for both saturated and air-dried blocks with and without the added fibers are presented in Table 3. The values for the blocks containing the sisal fibers are smaller than those for the blocks without fibers. This difference results because the fibers and voids introduced by them act as air-entrainment agents.

\subsection{Compressive strength of the blocks}

Table 4 shows the average and characteristic compressive strengths, $\left(f_{b m}\right)$ and $\left(f_{b k}\right)$, respectively, of the blocks. The testing was performed 28 days after the blocks and elements were made.
As can be seen from the results of the compression tests, the blocks containing sisal fibers showed an average decrease of $41 \%$ in resistance compared with that of the reference blocks. The ANOVA performed on these results indicated that the average values for the reference and fiber-containing samples were different. In particular, the compressive strength of the blocks without the added fibers was significantly higher than that of the blocks with the added fibers at a $95 \%$ confidence level.

This result can be linked to the lower densities of the blocks containing the fibers. It is also likely that other factors contributed to the strength reduction, such as weak interactions between the fibers and cement matrix, causing damage to the structure of the material. In addition, it was difficult to mold, press, and compact the dry concrete containing the added sisal, which may have led to the formation of defects in the blocks.

With respect to the characteristic strength, all blocks met the criteria for the 4-MPa class, which had been requested by the manufacturer. In Table 4, it can be observed that the blocks with 20-mm-long fibers had a higher resistance than the blocks with 40-mm-long fibers. This result may be related to the fact that the smaller fibers were better accommodated and distributed in the relatively small blocks compared with the larger fibers. On the basis of the ANOVA test with two factors, it was concluded that the length influenced the compressive strength of the reinforced blocks; the units containing 20-mm-long fibers exhibited a higher resistance compared with the units containing $40-\mathrm{mm}$-long fibers for a given fiber content at a significance level of 0.05 .

Finally, the resistance of the blocks with a fiber content of $0.5 \%$ and $1 \%$ were similar for both fiber lengths. The resistance of the blocks with $1 \%$ fiber content was slightly greater than that for the blocks containing $0.5 \%$ fibers. However, the two-way ANOVA test

Table 3 - Specific density of the blocks with and without fiber

\begin{tabular}{|ccccccc|}
\hline & \multicolumn{3}{c}{ Density air dried $\left(\mathbf{g} / \mathrm{cm}^{3}\right)$} & \multicolumn{3}{c|}{ Density saturated $\left(\mathrm{g} / \mathrm{cm}^{3}\right)$} \\
Block type & Average & $\mathrm{S}_{\mathrm{d}}$ & C.V $(\%)$ & Average & $\mathrm{S}_{\mathrm{d}}$ & C.V $(\%)$ \\
\hline BE & 2,18 & 0,04 & 1,63 & 2,33 & 0,01 & 0,20 \\
BE20-0,5\% & 2,12 & 0,01 & 0,65 & 2,27 & 0,02 & 0,67 \\
BE40-0,5\% & 2,08 & 0,01 & 0,67 & 2,26 & 0,01 & 0,31 \\
BE20-1\% & 2,11 & 0,05 & 0,03 & 2,28 & 0,03 & 1,48 \\
BE40-1\% & 2,13 & 0,03 & 1,15 & 2,33 & 0,01 & 0,61 \\
\hline
\end{tabular}

Table 4 - Compressive strength of the blocks

\begin{tabular}{|c|c|c|c|c|}
\hline \multirow{2}{*}{ Block type } & \multicolumn{4}{|c|}{ Compressive strength of the blocks (MPa) } \\
\hline & Average resist. $\left(f_{b m}\right)(M P a)$ & $S_{d}(M P a)$ & C.V (\%) & Charact. strength $\left(\mathrm{f}_{\mathrm{bk}}\right)(\mathrm{MPa})$ \\
\hline $\mathrm{BE}$ & 11,26 & 1,06 & 9,42 & 9,43 \\
\hline BE20-0,5\% & 7,11 & 0,48 & 6,79 & 6,25 \\
\hline BE $40-0,5 \%$ & 6,00 & 0,61 & 10,24 & 4,81 \\
\hline BE20-1\% & 7,16 & 1,22 & 13,03 & 6,10 \\
\hline BE $40-1 \%$ & 6,43 & 0,78 & 12,12 & 5,22 \\
\hline
\end{tabular}




\section{Table 5 - Compressive strength of prisms with and without fiber addition}

\begin{tabular}{cccc|}
$\begin{array}{c}\text { Prism } \\
\text { type }\end{array}$ & $\begin{array}{c}\text { Average } \\
\text { resist. }\left(\mathrm{f}_{\mathrm{p}}\right) \\
(\mathrm{MPa})\end{array}$ & $\mathrm{S}_{\mathrm{d}}(\mathrm{MPa})$ & $\mathrm{C.V}(\%)$ \\
\hline PR & 5,19 & 1,02 & 14,56 \\
PR20-0,5\% & 3,49 & 0,41 & 11,67 \\
PR40-0,5\% & 3,25 & 0,35 & 10,86 \\
PR20-1\% & 4,37 & 0,41 & 9,34 \\
PR40-1\% & 3,82 & 0,75 & 13,69 \\
\hline
\end{tabular}

showed that there was no statistical difference in the average values for the compressive strength of the blocks with $0.5 \%$ and $1 \%$ added fiber.

\subsection{Compressive strength of the prisms}

The values for the compressive strength of the prisms correspond to the gross area $\left(f_{p}\right)$ and are presented in Table 5 .

According to the statistical analysis, there were significant differences between the means of the five samples. In particular, the compressive strength of the prisms without the added fibers was greater than that of the prisms containing fibers at a confidence level of $95 \%$. In fact, the prisms reinforced with fibers showed an average decrease of $28 \%$ in resistance compared with the resistance of the prisms without any fibers.

Furthermore, the prisms with 20-mm-long sisal fibers showed better performance and greater resistance than the prisms with 40-mm-long fibers at a given fiber content. The two-way ANOVA test showed that the fiber length influenced the compressive strength of the reinforced prisms. Thus, the prisms containing 20-mm-long fibers exhibited higher strength than the prisms containing 40-mm long fibers $40 \mathrm{~mm}$ fibers for the same fiber content at a significance level of 0.05 .

With respect to the volume fraction of fibers, the prisms with $1 \%$ added sisal fibers of the same length exhibited higher performance. This factor was more significant in prisms than in blocks, and thus, the fibers contributed more to the bearing capacity of the element. As a result, the fiber content actually influenced the compressive strength of the prisms.

\section{Table 6 - Compressive strength of small walls with and without fiber addition}

\begin{tabular}{cccc|}
$\begin{array}{c}\text { Element } \\
\text { type }\end{array}$ & $\begin{array}{c}\text { Average } \\
\text { resist. }\left(\mathrm{f}_{\mathrm{pp}}\right) \\
(\mathrm{MPa})\end{array}$ & $\mathrm{S}_{\mathrm{d}}(\mathrm{MPa})$ & $\mathrm{C} . \mathrm{V}(\%)$ \\
\hline MN & 3,08 & 0,70 & 22,68 \\
$\mathrm{MN} 20-0,5 \%$ & 2,95 & 0,37 & 12,41 \\
\hline $\mathrm{MN} 40-0,5 \%$ & 2,96 & 0,19 & 6,57 \\
MN 20-1\% & 3,30 & 0,31 & 9,49 \\
\hline MN 40-1\% & 3,07 & 0,22 & 7,04 \\
\hline
\end{tabular}

\subsection{Compressive strength of the small walls}

The results of the tests on the compressive strength of the small walls in relation to the gross area $\left(f_{p p}\right)$ are shown in Table 6 . Note that no significant change in the compressive strength of the small walls was observed when blocks containing sisal fibers were used, and the values very close to or even higher than those obtained for the smaller walls constructed with blocks that did not contain any fibers were obtained. In fact, the elements consisting of blocks with $1 \%$ added $20-\mathrm{mm}$-long fibers had a higher resistance than the walls constructed of blocks without the added fibers. In addition, according to the ANOVA test, the means of the samples were similar at a significance level of 0.05 .

This result may be associated with the mechanical behavior of the blocks and elements, which differs for each type of component and element tested. Larger tensile stresses appear in the walls mainly because of the lagged vertical joints. Under this type of stress, the fibers act as efficient reinforcement. The horizontal tensile stresses were lower in the prisms than in the walls because they were generated solely due to the difference in the rigidity of the blocks and mortar. Moreover, in the prisms, and particularly in the blocks, the compression test is always characterized by a certain confinement effect that contributes to a reduction in the tensile stresses in the units.

The ANOVA test revealed that neither the length nor the fiber content significantly influenced the compressive strength. Thus, it can be concluded that the increase in the compressive strength of the elements with added $20-\mathrm{mm}$-long fibers was not statistically significant in comparison with the fiber elements containing 40-mm-long fibers for a given fiber content. The same conclusion can be drawn

Table 7 - Module deformation of the prisms with or without addition of fiber

\begin{tabular}{|ccccccc|}
$\begin{array}{c}\text { Type } \\
\text { of prisms }\end{array}$ & $\begin{array}{c}f_{\mathrm{p}} \\
(\mathrm{MPa})\end{array}$ & $\begin{array}{c}\text { Def. module } \\
\left(\mathrm{E}_{\mathrm{p}}\right)(\mathrm{MPa})\end{array}$ & $\begin{array}{c}\mathrm{S}_{\mathrm{p}} \\
(\mathrm{MPa})\end{array}$ & $\mathrm{C.V}(\%)$ & $\begin{array}{c}\text { Def. 33\% } \\
(\%)\end{array}$ & $\begin{array}{c}\text { Def. Iast } \\
(\%)\end{array}$ \\
\hline PR & 5,19 & 5283,86 & 377,15 & 7,13 & 0,28 & 1,18 \\
PR20-0,5\% & 3,49 & 3528,03 & 534,07 & 15,13 & 0,31 & 2,10 \\
PR40-0,5\% & 3,25 & 3084,64 & 460,61 & 14,93 & 0,55 & 3,93 \\
PR20-1\% & 4,37 & 4484,49 & 560,42 & 12,49 & 0,31 & 2,22 \\
PR40-1\% & 3,82 & 3916,51 & 389,01 & 9,93 & 0,32 & 2,20 \\
\hline
\end{tabular}


Post-cracking behavior of blocks, prisms, and small concrete walls reinforced with plant fiber

Figure 8 - Stress-strain curves of each type of prisms
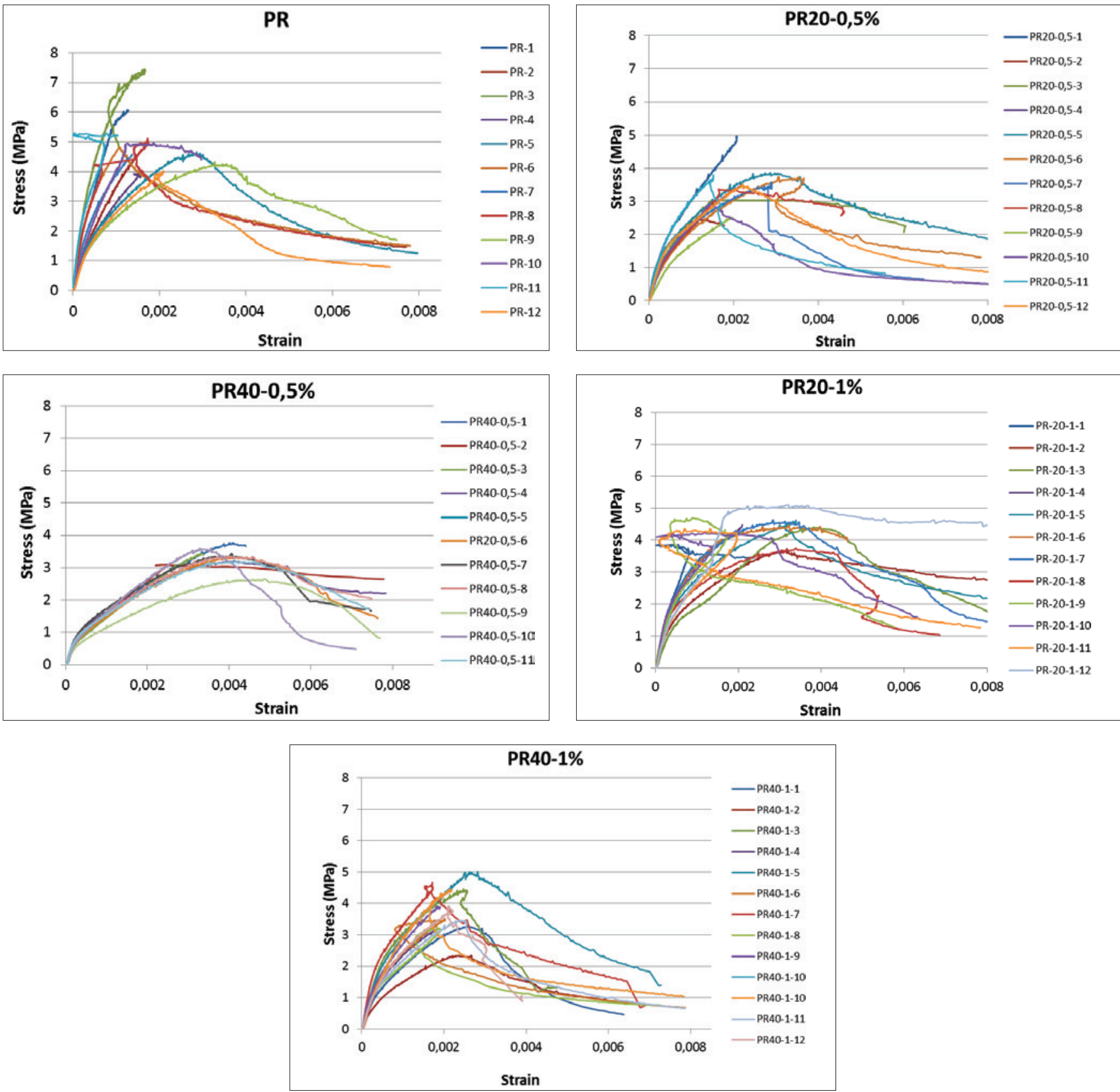

Table 8 - Deformation modulus of the small walls with and without fiber addition

\begin{tabular}{ccccccr|}
$\begin{array}{c}\text { Type of } \\
\text { small walls }\end{array}$ & $\begin{array}{c}f_{\mathrm{pp}} \\
(\mathrm{MPa})\end{array}$ & $\begin{array}{c}\text { Def. module } \\
\left(\mathrm{E}_{\mathrm{pp}}\right)(\mathrm{MPa})\end{array}$ & $\begin{array}{c}\mathrm{S}_{\mathrm{d}} \\
(\mathrm{MPa})\end{array}$ & C.V $(\%)$ & $\begin{array}{c}\text { Def. 33\% } \\
(\%)\end{array}$ & $\begin{array}{c}\text { Def. Iast } \\
(\%)\end{array}$ \\
MN & 3,08 & 5332 & 541,23 & 9,56 & 0,19 & 1,30 \\
MN 20-0,5\% & 2,95 & 4720 & 487,65 & 11,54 & 0,23 & 1,68 \\
MN 40-0,5\% & 2,96 & 4444 & 698,32 & 10,45 & 0,25 & 1,71 \\
MN 20-1\% & 3,30 & 5243 & 419,69 & 12,47 & 0,20 & 1,47 \\
MN 40-1\% & 3,07 & 4347 & 578,36 & 11,98 & 0,22 & 2,01 \\
\hline
\end{tabular}


for the increase in the compressive strength with the added fiber content from $0.5 \%$ to $1.0 \%$ for fibers of the same length.

\subsection{Deformation modulus and stress-strain curves for the prisms and small walls}

The deformation modulus was calculated for the prisms and small walls in accordance with the requirements of ACl 530-92 [12]. According to this standard, the modulus is given by the inclination of the secant line in the stress-strain curve between $5 \%$ and $33 \%$ of the breaking strain.

The results for the modulus of deformation of the prisms $\left(E_{p}\right)$ are presented in Table 7. Notably, both strain and modulus refer to the gross area of the elements. The Def. $33 \%$ column shows the deformation at $33 \%$ of the breaking strain, and the Def. Last column indicates the deformation at the moment of breakage.

The rigidity of the prisms containing the added fibers was lower than that of the prisms without the fibers. The deformation modulus of the prisms with the added fibers underwent an average reduction of $28 \%$ compared with the values for the prisms that did not contain any fibers. In the study conducted by Picanço [4], the same tendency was observed in composites with added vegetable fibers The stress-strain curves were drawn and organized by type of prism in Figure 8.

According to the diagrams, there is variation in the results, and thus, it impossible to determine the deformability and effect of the pres-

Figure 9 - Stress-strain curves of each type of small walls
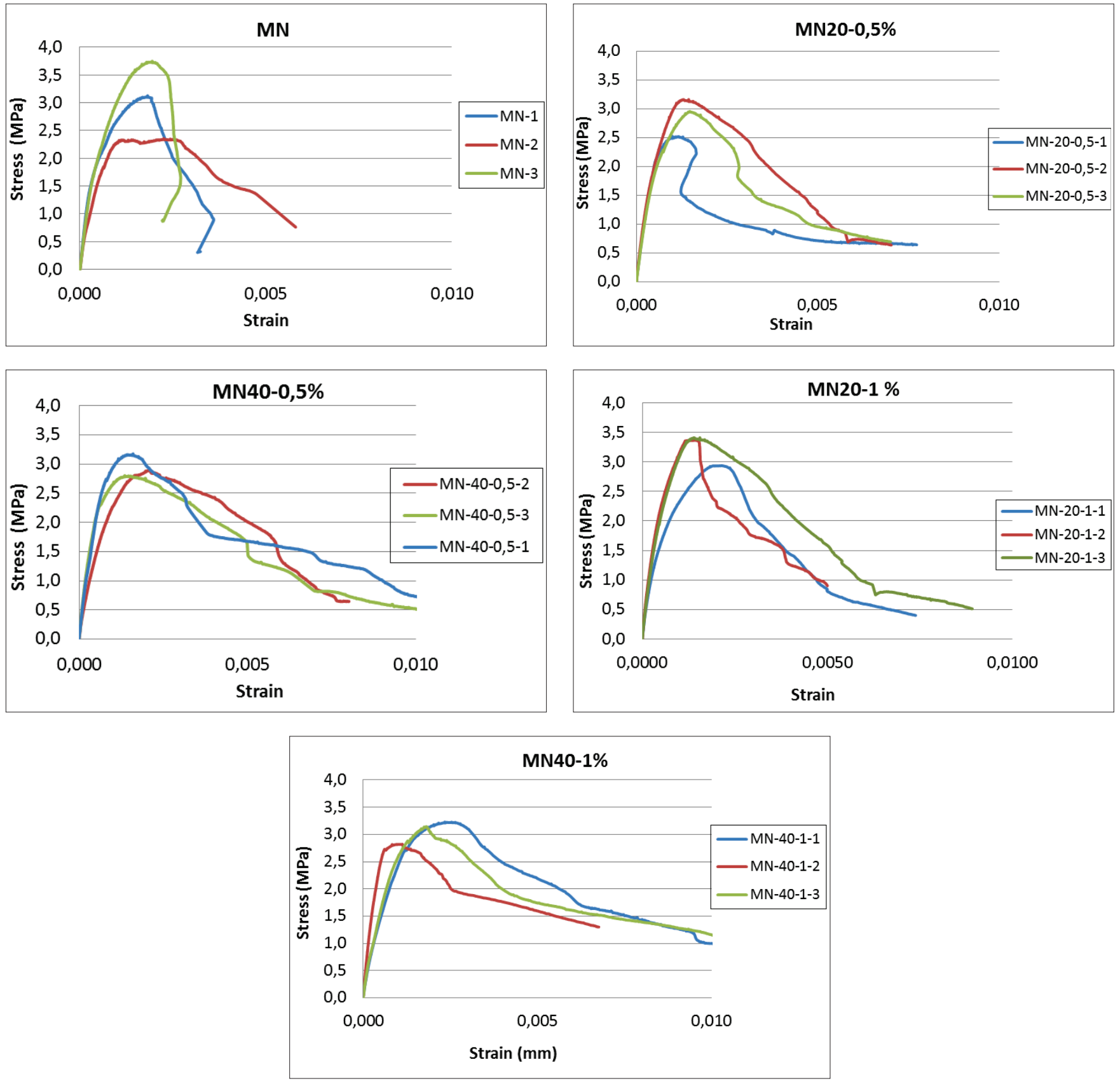


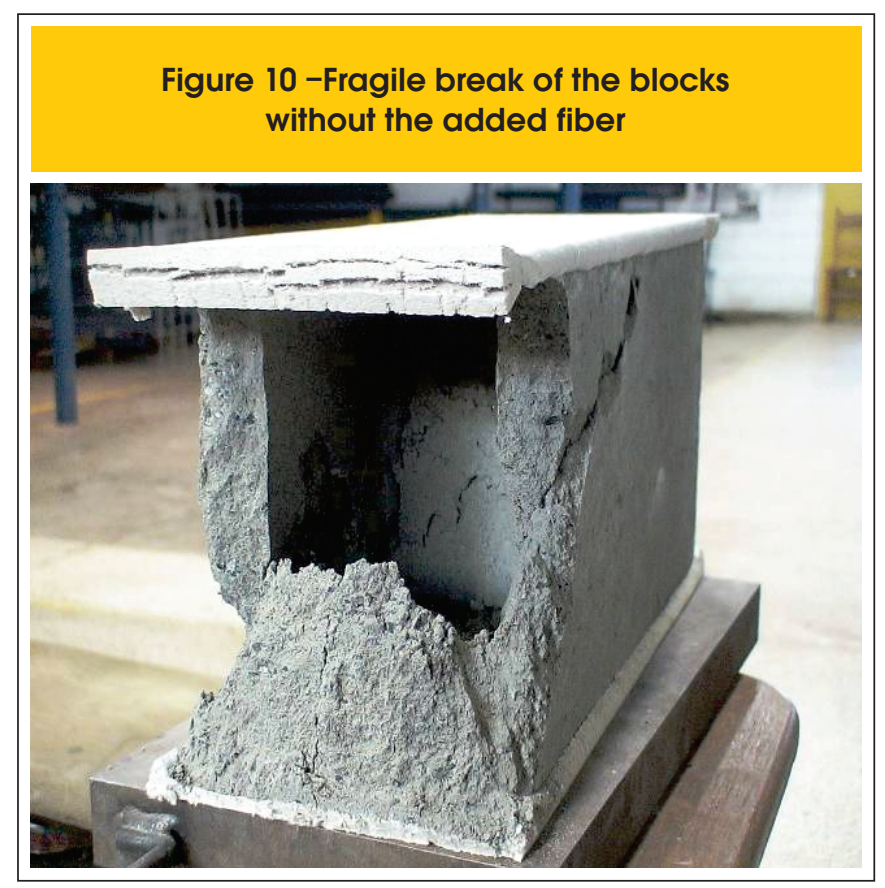

ence of the fibers in the blocks. This variation may be associated with the loading and unloading cycles, which were only performed up to $10 \%$ of the failure load expected for the prisms. It is probable that the execution of the cycles up to $30 \%$ of the ultimate load would lead to a reduction in the variability and enable analysis of the data. In the PR20-1\% graph, it can be observed that stress concentration occurred at one side of the prism, causing crushing and tensile stresses in the meter positioned on the opposite side. This result can be verified by the tie formed in the stress-strain curve near the rupture.

Although the stress-strain curves of the prisms could not be used to better visualize the results, note that most reinforced elements showed extension of the post-peak curves. Thus, it can be said that there was a gain in capacity for the absorption of deformation and that the addition of the fibers was advantageous with respect to im-

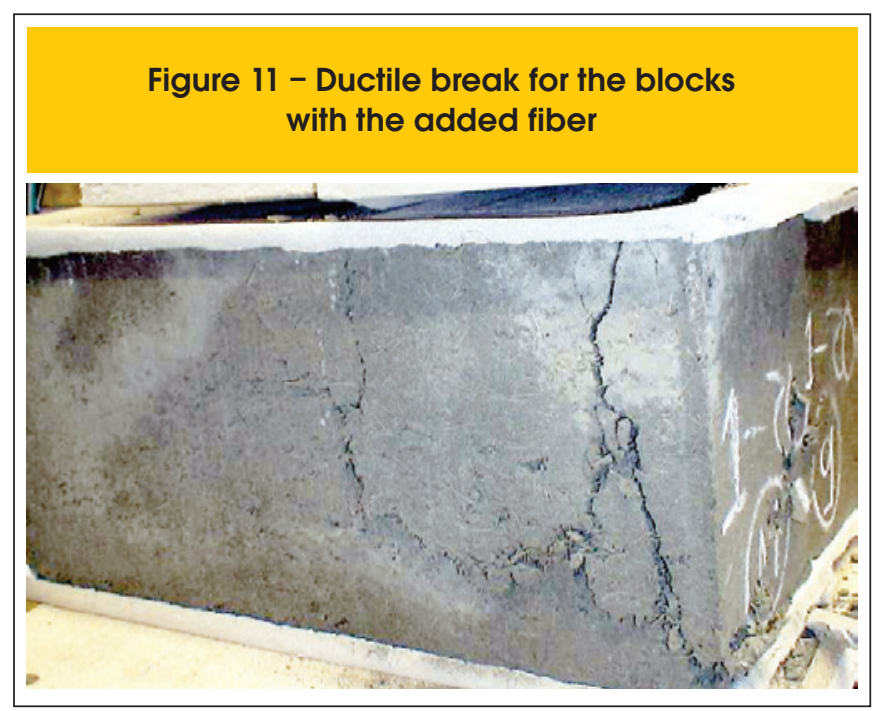

proving the ductility and resilience of residual matrix after cracking. Table 8 shows the results for the modulus of deformation for the small walls $\left(E_{p p}\right)$. There was a small decrease in the rigidity of the walls with the addition of fibers to the blocks compared with that of the walls constructed with blocks that did not contain fibers. This reduction was equal to approximately $12 \%$, considering the overall average.

The stress-strain curves for the small walls are arranged in Figure 9 according to each sample type. No marked difference was observed in the compressive strength of the walls for different samples. Thus, it can be clearly noted that the addition of sisal fibers to the blocks used to construct these elements contributed to a gain in the deformation capacity.

According to Savastano [1], cracks begin to form at the time of composite failure, but their growth is constrained by the presence of fibers. When the cracks begin to join, the sum of their effects influences the toughness of the element due to large deformation of the material. In this case, there is an explanation for the increased toughness afforded by the addition of fibers because they are responsible for incorporation of voids and discontinuities; these fibers can absorb an increased amount of energy during cracking while at the same time limiting the spread of the cracks.

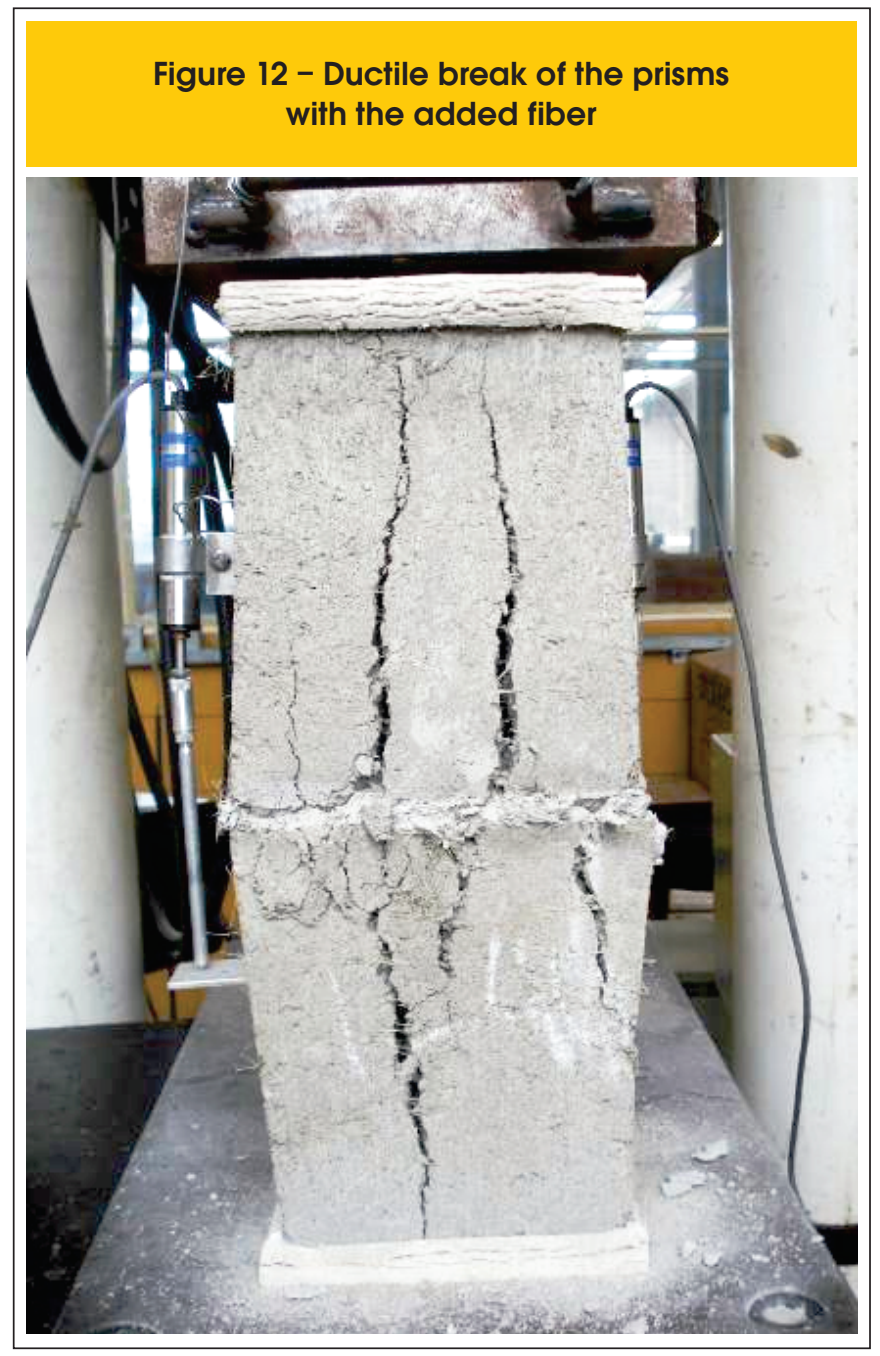




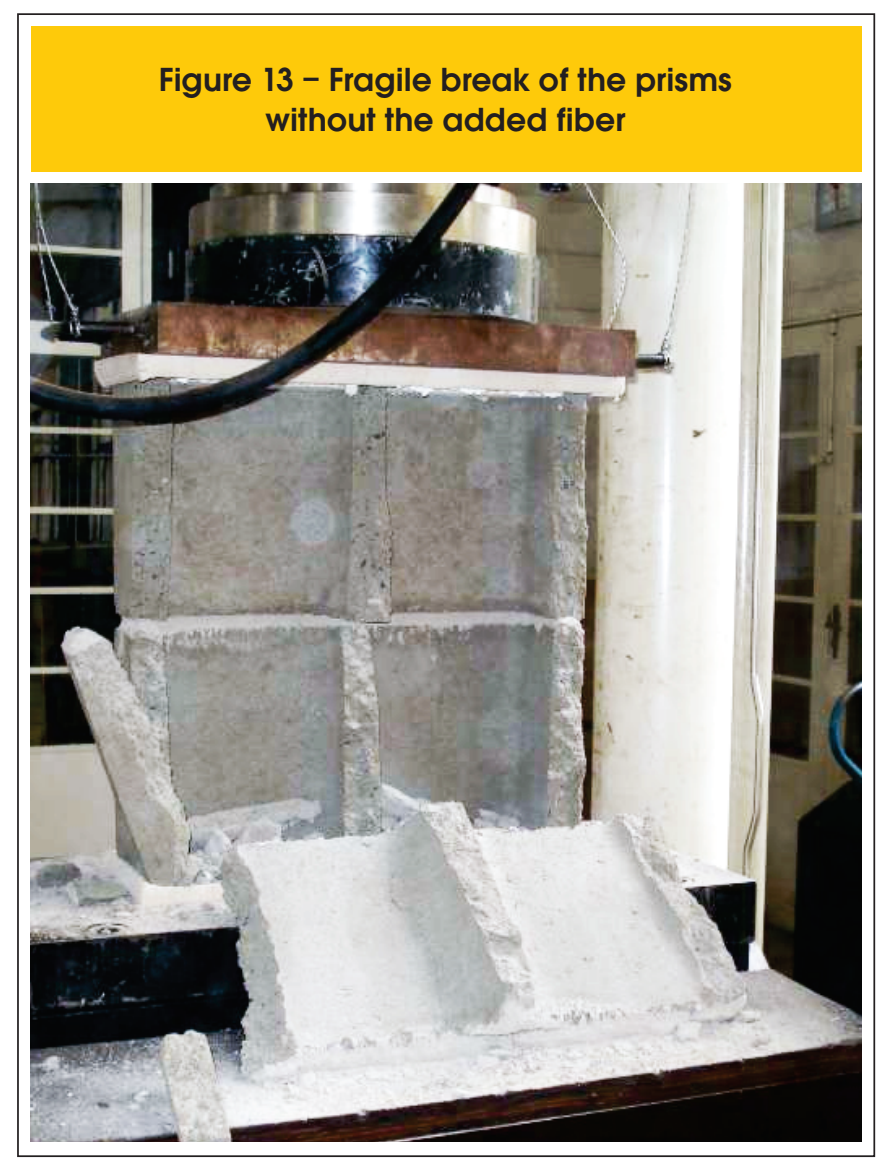

\subsection{Rupture type for the elements}

It was observed during the compression tests that an instant collapse occurred in the nonreinforced units (Figure 10). In contrast, the blocks reinforced with sisal fibers did not undergo a brittle fracture, as shown in Figure 11.

The same behavior was observed for the prisms. The elements with

\begin{tabular}{|cccc|}
\hline \multicolumn{5}{|c|}{$\begin{array}{c}\text { Table 9 - First cracking load and } \\
\text { breaking load of small walls }\end{array}$} \\
Type of & $\begin{array}{c}\text { First cracking } \\
\text { load }\left(P_{1}\right)\end{array}$ & $\begin{array}{c}\text { Breaking } \\
\text { load }\left(P_{R}\right)\end{array}$ & $\begin{array}{c}\text { Ratio } \\
P_{1} / P_{R}(\%)\end{array}$ \\
small walls & $(k N)$ & $(k N)$ & 77,06 \\
& 261,26 & 340,16 & 82,43 \\
MN & 263,29 & 318,54 & 84,05 \\
MN 20-0,5\% & 275,04 & 327,13 & 91,33 \\
MN 40-0,5\% & 332,95 & 364,56 & 89,22 \\
\hline MN 20-1\% & 302,51 & 339,06 & \\
\hline MN 40-1\% & & & \\
\hline
\end{tabular}

added sisal fibers experienced a ductile rupture, with the fragments remaining linked by the fibers due to their adhesion to the matrix (Figure 12). However, a sudden rupture occurred in the elements without fibers, which is characteristic of brittle behavior (Figure 13). The parts of the reinforced elements, even after they were broken, were held together by the fibers, and thus, the elements did not lose their continuity and the breaks were progressive. According to Campos [15], this behavior indicates that the fibers were capable of joining the faces of the cracks. As a result, they imparted a certain load capacity after cracking, although small, that contributed to an increase in the toughness of the elements containing them. Another advantage of using the fibers as a reinforcement material in concrete is delayed cracking, which leads to improved system performance. Table 9 shows the first cracking load and its relationship to the ultimate strength of the small walls. As observed, the first cracking load of the walls containing the fibers occurred at a higher percentage relative to the final strain, and there was a delay in the cracking of these elements.

\subsection{Cracking of the prisms and small walls}

In the prisms, in most cases, vertical cracks developed along the lateral septa. The cracks were initiated near the mortar joints and

Figura 14 - Typical break of the prisms under compression
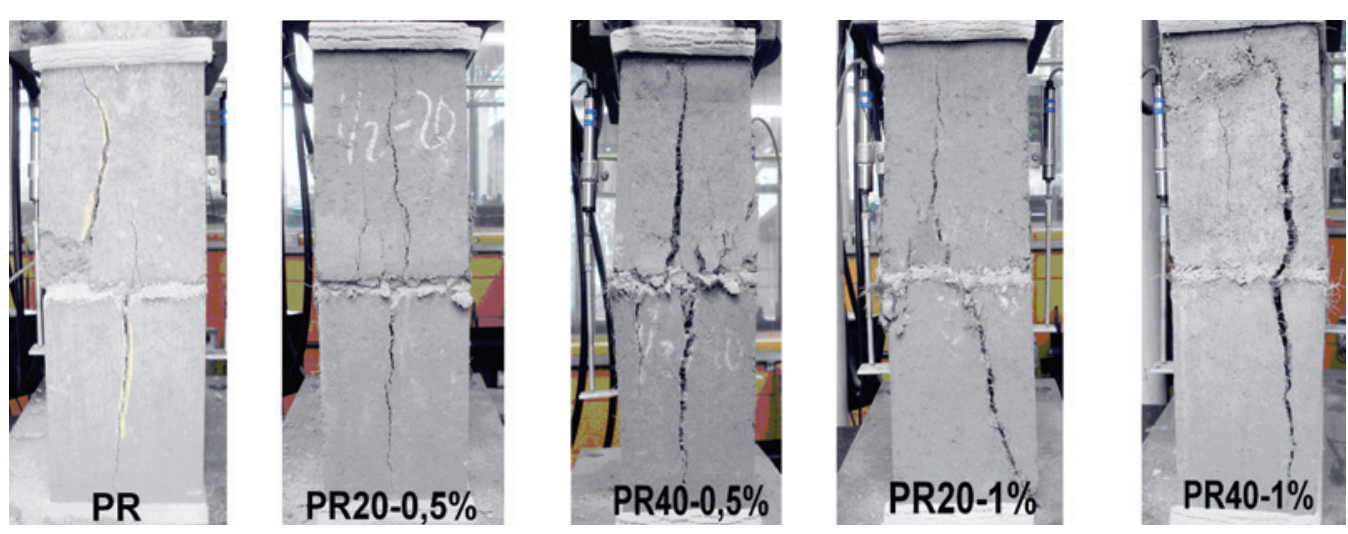
Figure 15 - Crack of propagation vertical traction
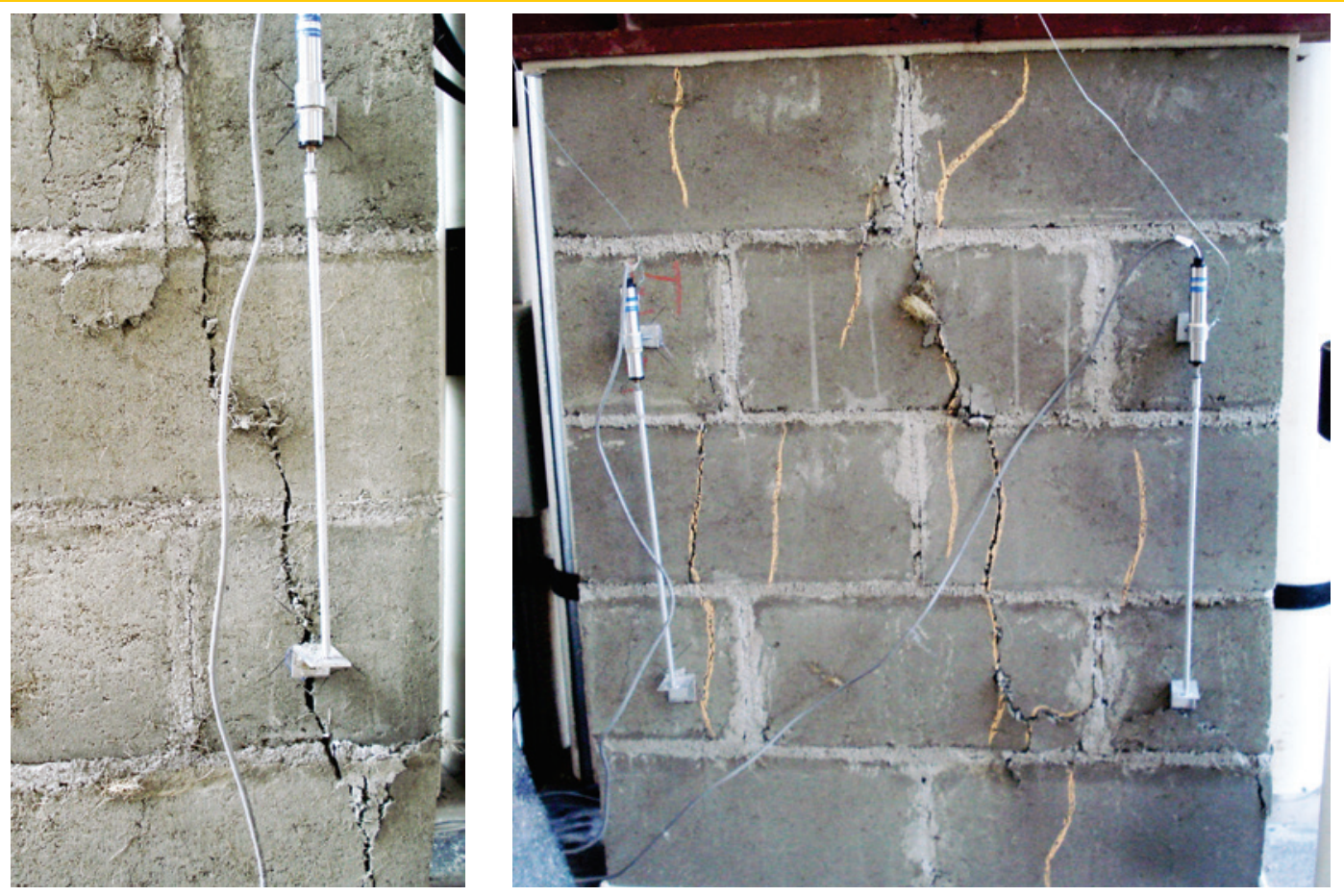

Figure 16 - Vertical cracks developed along the lateral septa
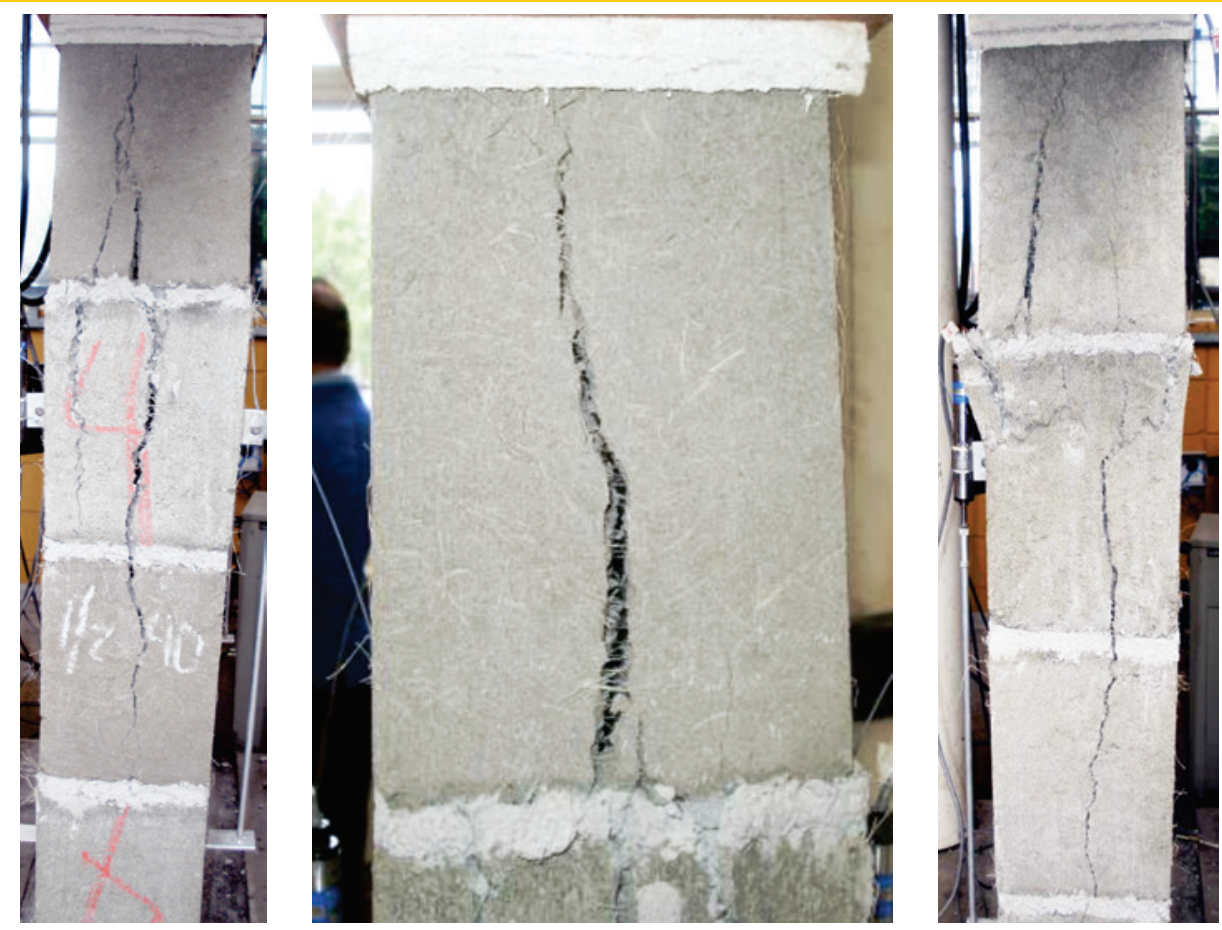
spread throughout the height of the element, with breakage by traction in the region near the joint. Figure 14 shows the typical crack formation for each type of prism.

According to Mohammed [16], because the mortar is less rigid than the blocks, which is true in most cases, there is a tendency for the mortar to deform more than the units. However, this deformation is prevented by the adherence to the other components, which gives rise to tensile stresses in the units transverse to the vertical axis of compression. With respect to cracking of the walls, vertical tensile cracks were observed that started at the vertical joints and progressed to the cutting blocks, leading to their rupture (Figure 15). The appearance of this type of cracking can be explained by the presence of vertical joints in these elements. In general, there were vertical cracks along the lateral septa, with breakage occurring because of transverse traction in the blocks, as illustrated in Figure 16. In most of the small walls without fibers and also in some of the small walls with the added fibers, crushing occurred between the horizontal and vertical joints (Figure 17).

\section{Conclusions}

- According to statistical studies, blocks containing fibers experienced a decrease of $41 \%$ in the average compressive strength compared with that of the reference blocks because of flaws in the material structure, although they exhibited the desired level of resistance. The reinforced prisms showed better performance than the reinforced blocks with an average decrease of $28 \%$ in strength compared with the reference prisms. In turn, the small walls with sisal fibers had a mean reduction of just $3 \%$ in the resistance compared with that of the standard elements.

- The small walls best represent the typical failure mode in masonry, in which larger tensile stresses appear in the units because of the lagged vertical joints. Under this type of stress, the fibers act as efficient reinforcement and can effectively contribute to the improvement of the resistant capacity of the material.

- Because sisal has a low deformation modulus, its functions mainly after matrix cracking. It enables greater energy absorption and imparts some ability to absorb loads after cracking, which helps to increase the toughness and ductility of the material.

- The failure mode was well characterized in all sample types tested. The units and elements with added fibers always underwent ductile rupture. However, sudden rupture occurred in the elements without fibers, which is characteristic of fragile behavior. Thus, the fibers united the faces of the cracks because of adhesion with the cement matrix and prevented loss of continuity of the material.

\section{Acknowledgments}

The authors would like to thank the Department of Structural Engineering of the School of Engineering of São Carlos at the University of São Paulo for permission to conduct the survey and the Structures Laboratory in the Department of Structural Engineering for the experimental program. The authors would also like to thank the Brazilian National Council for Technological and Scientific Development $(\mathrm{CNPq})$ for financial support provided to this research.

\section{References}

[01] SAVASTANO, H. J. Materiais à base de cimento reforçado com fibra vegetal: reciclagem de resíduos para a construção de baixo custo. 2000, 7p, 22 p. Tese (Livre-Docência em Engenharia Civil) - Escola Politécnica da Universidade de São Paulo, São Paulo, 2000.

[02] PEREIRA, P. S. Estudo da viabilidade do aproveitamento de fibras vegetais como reforço de matrizes cimentícias. 2004, In: XIII Seminário de Iniciação Científica e

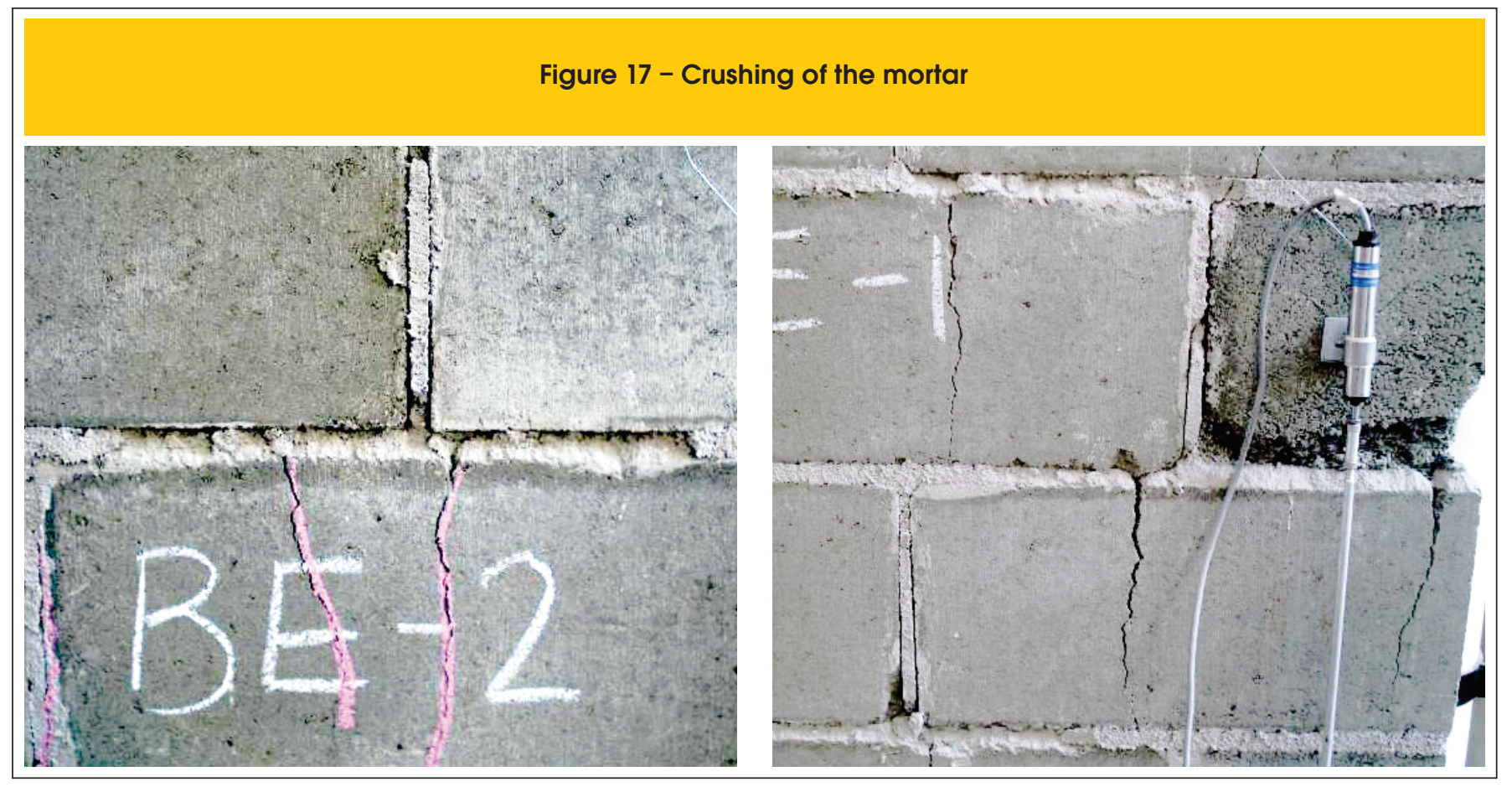


9a Semana de Pesquisa e Pós-Graduação da UES Ciências Exatas, da Terra e Engenharias, 2004.

[03] VENTURA, O.S.P. Caracterização mecânica de compósitos reforçados com fibras de sisal. 2007, In: Workshop de Recursos não renováveis, Natal, RN, 2007.

[04] PICANÇO, M. S. Compósitos cimentícios reforçados com fibras de curauá. 2005. 25 p. Dissertação (Mestrado em Engenharia Civil) - Pontifícia Universidade Católica do Rio de Janeiro, Rio de Janeiro, 2005.

[05] SAVASTANO, H. J. Zona de transição entre fibras e pasta de cimento Portland: Caracterização e inter-relação com as propriedades mecânicas do compósito. 1992, 21 p. Tese (Doutor em Engenharia Civil) - Escola Politécnica da Universidade de São Paulo, São Paulo, 1992.

[06] CAETANO, L.F. et al. Compósito de matriz cimentícia reforçada com fibras. In: II Seminário de Patologia das edificações. 2004, Porto Alegre. Anais .... Porto Alegre: UFRGS, 2004. p. 4.

[07] MEDEIROS, J.S; SABBATINI, F.H. Alvenaria estrutural não armada de blocos de concreto: produção de componentes e parâmetros de projeto. Boletim Técnico da Escola Politécnica da USP- Departamento de Engenharia de Construção Civil, São Paulo, 1993.

[08] SOLÓRZANO, M. G. Características e desempenho de juntas de argamassa na alvenaria estrutural de blocos de concreto. 1994, 60p. Dissertação (Mestrado em Engenharia Civil) - Escola Politécnica da Universidade de São Paulo, São Paulo, 1994.

[09] ASSOCIAÇÃO BRASILEIRA DE NORMAS TÉCNICAS. NBR 12118: blocos vazados de concreto simples para alvenaria- Métodos de ensaio. Rio de Janeiro, 2007.

[10] NBR 8215: Prismas de blocos vazados de concreto simples para alvenaria estrutural - Preparo e ensaio à compressão. Rio de Janeiro, 1983.

[11] . NBR 8949: Paredes de alvenaria estrutural Ensaio à compressão simples. Rio de Janeiro, 1985.

[12] AMERICAN CONCRETE INSTITUTE. ACI 530-92: Building code requirements for masonry. structures and specifications for masonry structures. Detroit. 1995.

[13] BRITISH STANDARDS INSTITUTION. BS 5628: Part 1. Code of practice for use of masonry Structural use of unreinforced masonry.London, 1992.

[14] TOLEDO FILHO, R. D. Materiais compósitos reforçados com fibras naturais: caracterização experimental. 1997, 93p. Tese (Doutorado em Engenharia Civil) Pontifícia Universidade Católica do Rio de Janeiro, Rio de Janeiro, 1997.

[15] CAMPOS, R. E. Desempenho à compressão de compósitos reforçados por fibras de coco. 2008, 7 p. Trabalho de Conclusão de Curso - Universidade Federal de Sergipe, Sergipe, 2008.

[16] MOHAMAD, G. Comportamento mecânico na ruptura de prismas de blocos de concreto. 1998. 178 p. Dissertação (Mestrado em Engenharia Civil) Universidade Federal de Santa Catarina, Florianópolis, 1998. 